\title{
Effectiveness of organic terrace rice cultivation in conservation of odonates in Sikkim, Eastern Himalaya, India
}

\author{
Sailendra Dewan $\mathbb{D}^{\mathrm{a} \dagger}$, Nikesh Darnal ${ }^{\mathrm{a} \dagger}$, Bhoj Kumar Acharya (D) ${ }^{\mathrm{a} *}, \mathrm{~K}$ A Subramanian ${ }^{\mathrm{b}}$, \\ Basundhara Chettri ${ }^{\mathrm{a}}$ and V J Jins ${ }^{\mathrm{a}}$ \\ ${ }^{a}$ Department of Zoology, School of Life Sciences, Sikkim University, Gangtok, Sikkim, India, ${ }^{b}$ Zoological \\ Survey of India, Southern Regional Centre, Chennai, India
}

(Received 9 October 2019; accepted 29 November)

\begin{abstract}
Conversion of natural habitat into agricultural landscape has been identified as one of the major drivers of habitat loss. Human-modified ecosystems, such as agricultural land, have gained significant attention in terms of the conservation of their native biodiversity. We studied the effectiveness of organic agroecosystems in conserving odonate diversity by comparing organic terrace rice cultivation with a nearby natural forest system with streams in Sikkim, Eastern Himalaya, India. We sampled adult odonates using a transect count method (laying six permanent transects) covering two villages (Lingmoo in South Sikkim and Dzongu in North Sikkim), making a total of 48 transect counts. A total of 881 individual odonates representing 31 species under two suborders (16 Anisoptera and 15 Zygoptera) and seven families were recorded during this study. Of these, 20 species representing three families and 18 species representing seven families were observed in terrace rice cultivation and the natural forest system, respectively. Beta diversity estimates showed that the community composition of the odonates differed qualitatively (incidence measure) and quantitatively (abundance measure) between the two land use types. Turnover component (abundance balance in case of abundance based beta diversity measure) had higher contribution in the overall beta diversity, suggesting that one assemblage of species is being replaced by another due to environmental sorting. The variation in community composition between the two habitats was statistically significant. Our results suggest that organic wetland habitats are important for conservation of odonates and associated biodiversity (especially herpetofauna) in the Himalaya and require urgent conservation attention.
\end{abstract}

Keywords: agroecosystem; aquatic habitat; biodiversity; dragonfly; damselfly; herpetofauna; Odonata

\section{Introduction}

Habitat loss and degradation have resulted in significant decline in biological diversity over the last decade (Brooks et al., 2002; Primack, 2014). Conversion of natural habitats into agricultural landscapes has been identified as one of the major drivers of habitat loss (Newbold et al., 2015) and a high percentage of red-listed species is known to be threatened by agricultural intensification (IUCN, 2015; Norris, 2008). Agricultural intensification is predicted to increase in the future to meet the food demand for the ever-increasing human population, resulting in higher numbers of threatened species and loss of natural ecosystems (Godfray et al., 2010). Environment friendly farming practices, which often involve traditionally and organically managed agroecosystems,

\footnotetext{
*Corresponding author. Email: bkacharya@cus.ac.in

$\dagger$ These authors contributed equally
} 
are some of the promising approaches that can maintain food security while safeguarding biodiversity. Such farming practices support higher species richness and abundance of organisms than conventional farming (Czech, 2002; Katayama et al., 2019; Lichtenberg et al., 2017; Tuck et al., 2014). The effectiveness of environment friendly farming practices often depends on use of organic approaches and availability of surrounding landscape as a source habitat for range of biodiversity (Baba, Kusumoto, \& Tanaka, 2019; Tscharntke, Klein, \& Kruess, 2005).

Habitat alteration due to agriculture intensification has been identified as one of the key drivers of local extinction of arthropods (Chung, Eggleton, Speight, Hammond, \& Chey, 2000; Clausnitzer et al., 2009; Lawton et al., 1998). Intensive expansion of rice fields is considered as the main reason for loss of habitat of many wetland species (Russi et al., 2013). Among aquatic arthropods, odonates represent a group which is severely affected by intensification of rice cultivation (Kadoya, Suda, \& Washitani, 2009). Odonates depend on a large number of environmental factors and their species assemblages are determined by different characteristics of the habitat, including water quality (Corbet, 1999; Gibbons, Reed, \& Chew, 2002; Scher \& Thiery, 2005). Alteration of natural habitat causes the replacement of forest specialists by generalist groups of odonates (Clausnitzer, 2003; Samways, 2003; Seidu, Danquah, AyineNsor, Amaning Kwarteng, $\&$ Lancaster, 2017). Studies from southern Brazil (Dalzochio, Baldin, Stenert, \& Maltchik, 2016), north-western Italy (Giuliano \& Bogliani, 2019) and Japan (Baba et al., 2019) have indicated the positive effect of environmental friendly practices of rice cultivation on odonate communities.

In India, rice cultivation is one of the primary agricultural practices and almost $55 \%$ of its overall population consumes rice (Jadhao \& Khurad, 2011). Rice is grown in 43.86 million hectares in India, making it an important semi-natural landscape (Ministry of Agriculture and Farmers Welfare, 2019). This landscape acts as a habitat for odonates to survive and reproduce, where natural habitats are unavailable. A total of 12 species of odonates were recorded from the rice fields of Madurai, Tamil Nadu (Kandibane, Raguraman, \& Ganapathy, 2005), 21 species from Tiruvallur district of Tamil Nadu (Anbalagan, Paulraj, \& Ignacimuthu, 2013), 13 species from Howrah district of West Bengal (Dwari and Mondal, 2017) and 14 species from Anand in Gujarat (Rohmare, Rathod, \& Parasharya, 2016). The diversity of odonates, however, was recorded to be lower in agricultural landscapes than in other natural systems (Kulkarni and Subramanian, 2013). Conventional methods of intensive agriculture are practised in almost every state in India. For example, $75 \%$ of farmers in Tamil Nadu use agrochemicals for their rice cultivation (Chitra, Muraleedharan, Swaminathan, \& Veeraraghavan, 2006). The use of agrochemicals, namely fertilizers and pesticides, had a significant negative effect on the population of odonates in rice fields in Karaikal, Puducherry, India (Soniyagandhi \& Kumar, 2014), indicating that intensive rice cultivation practices pose a serious threat to odonate diversity in agricultural landscapes.

The agroecosystem in Sikkim, a small state of India, comprises of an agroforestry system with forest habitat surrounding the agricultural landscape (Sharma, Chettri, Gurung, \& Shakya, 2007). Sikkim was recently declared as an organically farming state in India (Bhutia, 2015). The agroforestry system of Sikkim was found to be effective in conserving high butterfly diversity, including species of conservation concern (Chettri, Sharma, Dewan, \& Acharya, 2018, Sharma et al., 2020). The rice agroecosystem in Sikkim comprises of about 10.67 thousand hectares of cultivated land (Sharma \& Acharya, 2013). These human-modified systems in the region can be crucial and serve as an alternative habitat for biodiversity, especially water dependent species including odonates.

The Odonata fauna of Himalaya is highly diverse, with 257 species in 112 genera and 18 families (Subramanian and Babu, 2017). The high diversity of Odonata is reported from Eastern Himalaya, especially in Sikkim-Darjeeling and Arunachal Pradesh (Mitra, 2003, 2004; Allen, Molur, \& Daniel, 2010). From the Sikkim-Darjeeling region alone, a total of 185 species of odonates including 13 endemics are reported (Allen et al., 2010; Payra \& Bhutia, 2017; Subramanian \& Babu, 2017). Additionally, the region is recognized as one of the global freshwater 
biodiversity hotspots (Allen, Molur, \& Daniel, 2010). Traditionally managed farming systems have been proved to be an alternative refuge for various taxa, both invertebrate and vertebrate (Kurniawan, Yanuwiadi, Priambodo, Maulidi, \& Kurnianto, 2016; Sharma et al., 2020). The terraced farming system in Sikkim also acts as refuge for various species of herpetofauna. Snake species such as Indo-Chinese rat snake (Ptyas korros), Himalayan keelback (Herpetoreas platyceps), checkered keelback (Xenochrophis piscator) and some frog species of the genus Fejervarya and Polypedates live in sympatry with odonates in paddy fields. These animals are considered as farmers' friends, as they control various pests such as rodents and insects. A recent study from lowland Nepal highlighted that frogs are potential biological control agents and thus an integral part of the rice paddy system (Khatiwada et al., 2016).

Earlier studies on odonates in the region focused mainly on taxonomic diversity and distribution. However, no systematic studies on association of odonates with agricultural systems have been carried out in Sikkim, where agricultural practices are fully organic. Therefore, this study was conducted to document the diversity of odonates in the rice agroecosystem of Sikkim Himalaya and to understand the effectiveness of such agroecosystems in conserving odonate diversity. Specifically, we compare the alpha and beta diversity of odonates between organic terrace rice cultivation (TRC) and nearby natural streams in the forests.

\section{Methodology}

\section{Study area}

Sikkim is a small hilly state of India with an area of $7096 \mathrm{~km}^{2}$ and is a part of the larger Himalaya biodiversity hotspot. The steep rise in elevation in this region causes adverse changes in climatic profile, resulting in huge variation in floral and faunal assemblages (Acharya, Sanders, Vijayan, \& Chettri, 2011). Two villages in Sikkim, Lingmoo and Dzongu, were selected for the present study (Figure 1). Lingmoo is a village in the South District of Sikkim, located at an elevation of $1100 \mathrm{~m}$. The vegetation consists of sub-tropical mixed broad-leaved hill forest. Dzongu village is located in the North District of Sikkim and has an elevation ranging from $800 \mathrm{~m}$ to $6100 \mathrm{~m}$. We considered elevations between 800 and $1000 \mathrm{~m}$ for this study because TRC studied here was available only within this range. The region supports the different vegetation types; however, the typical vegetation of our study sites was sub-tropical broad-leaved forest. The agricultural ecosystem of these regions typically consists of cultivated land interspersed between patches of natural forest. The details of these land use systems are given below.

Terrace rice cultivation (TRC) This system mostly consists of cultivation of rice in artificially created terraced lands (Figure 2). Unlike in mainland plains of India, rice in Sikkim is grown in water-fed terraced steep terrain. Indigenous varieties of rice, which only grow in the ambient climatic conditions of the region, make TRC a unique agricultural area and important ecosystem. Due to its extensive irrigation and water drainage system, TRC forms an important artificial habitat for odonates and some species of amphibians and reptiles.

Natural forest system with streams (NFS) The landscape of the study area consists of patches of privately owned forests, community managed forest or continuation of protected forest around the vicinity of agricultural land (although protected forests were not considered in the present study). The local community chiefly depends on these forests for fuelwood, fodder, herbal medicine and also for some wild edibles. Forest around the elevation of 900-1200 m (the range covered during this study) mostly comprises of Alnus nepalensis, Schima wallichi, Castanopsis 


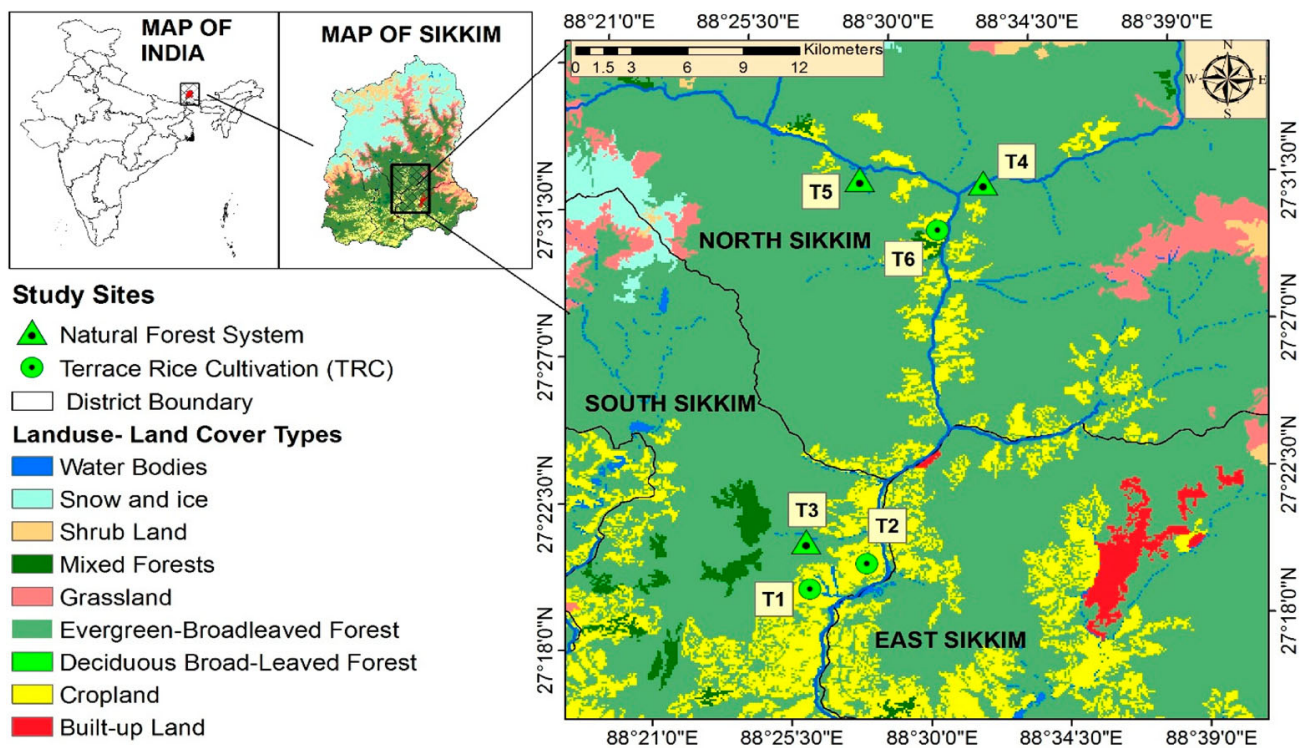

Figure 1. Map showing the study sites of Odonates in Lingmoo (South Sikkim) and Dzongu (North Sikkim), Eastern Himalaya.

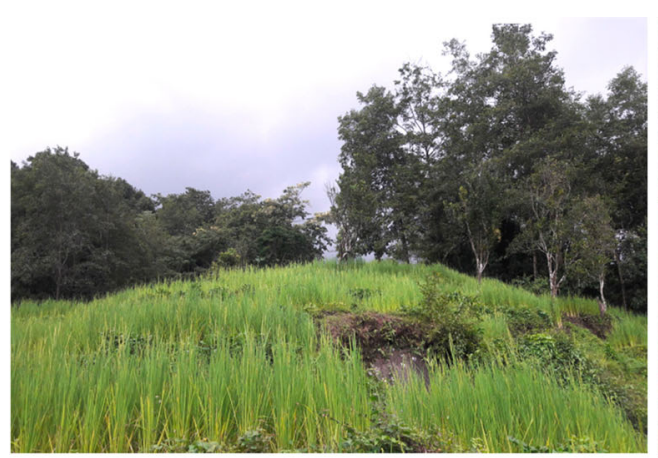

(A)

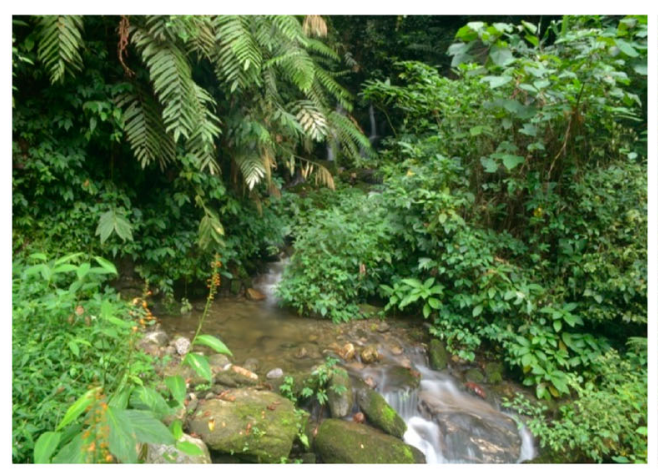

(C)

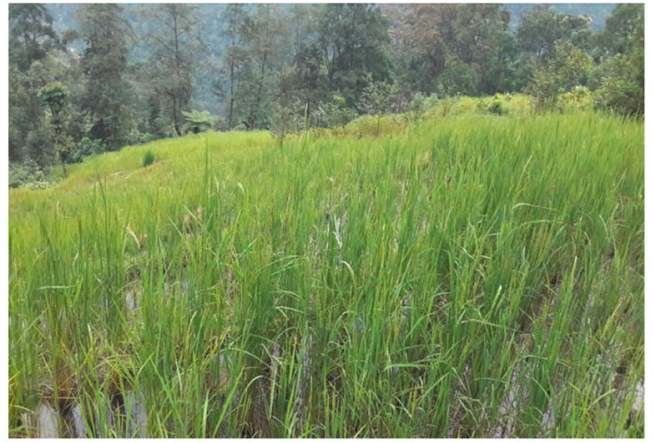

(B)

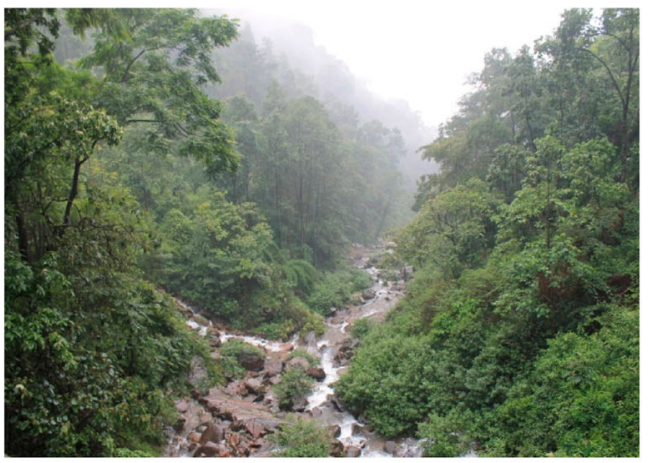

(D)

Figure 2. Photographs showing two habitat types: terrace rice cultivation (A, B) and natural forest with streams (C, D) considered for the study in Sikkim, Eastern Himalaya. 
Table 1. Details of transects laid for the study of Odonates in Sikkim, Eastern Himalaya, India.

\begin{tabular}{|c|c|c|c|c|c|}
\hline Transect & Village & Elevation (m) & Latitude $\left({ }^{\circ} \mathrm{N}\right)$ & Longitude $\left({ }^{\circ} \mathrm{E}\right)$ & Habitat type \\
\hline $\mathrm{T} 1$ & Lingmoo & 965 & 27.33590 & 88.46672 & NFS \\
\hline $\mathrm{T} 2$ & Lingmoo & 1133 & 27.34113 & 88.46270 & TRC \\
\hline $\mathrm{T} 3$ & Lingmoo & 1043 & 27.34037 & 88.46495 & TRC \\
\hline $\mathrm{T} 4$ & Dzongu & 816 & 27.52120 & 88.53145 & NFS \\
\hline T5 & Dzongu & 956 & 27.50283 & 88.51978 & TRC \\
\hline T6 & Dzongu & 998 & 27.52695 & 88.51335 & NFS \\
\hline
\end{tabular}

Abbreviations: NFS, natural forest system with streams; TRC, terrace rice cultivation.

indica, Engelhardtia spicata, Macaranga indica and Terminalia myriocarpa, as dominant vegetation. Lantana camara, Rubus niveus and Boehmeria sp. mainly dominates the undergrowth vegetation. Water bodies such as streams and rivulets present in this ecosystem are mostly undisturbed and free from anthropogenic disturbances (Figure 2). The natural water bodies provide habitat to aquatic and amphibious organisms that depend on a moist forest environment.

\section{Odonata sampling}

We sampled adult odonates using a transect count method following the line of least resistance. Three permanent line transects of $200 \mathrm{~m}$ length and $5 \mathrm{~m}$ width were laid in both the TRC and nearby streams in the NFS, making six transects in total (Table 1, Figure 1). Transects were laid along artificial rivulets, water channel and paddy pools in the TRC system. Natural forest areas with streams were selected as reference sites for comparison of odonates between disturbed and reference habitats. Transects in NFS were laid along the stream line with forest cover. A slow and steady pace was maintained during the transect walk and all the odonates found within $5 \mathrm{~m}$ band on both sides of the transect were recorded through visual observation. Sampling was carried out between 09:00 and 14:00 hours during calm and sunny weather days because most odonates are active and the probability of encounter was high during this time. While most individuals were identified visually without capturing, species which could not be identified easily (e.g. Pseudagrion sp. and Calicnemia sp.) were captured with the help of a sweep net, and released after taking notes on essential morphological characters. The odonates which remained unidentified in the field were photographed and later identified with the help of the official portal of odonates of India (Joshi, Dawn, Roy, \& Kunte, 2019) and available literature (Fraser, 1933, 1934, 1936; Mitra, 2003; Subramanian, 2005; Subramanian \& Babu, 2017). Sampling was conducted during the months of July 2018 to April 2019 covering all major seasons. A total of 25 and 23 transect count were made in the TRC and NFS respectively. No collection of the samples for preservation was made during the study.

\section{Data analysis}

Community parameters such as species richness, abundance, and alpha and beta diversity indices were calculated for odonates of the study area. Species richness was considered as the total number of species encountered during the survey and abundance as the total number of individuals of the odonates. Non parametric estimators were also computed to estimate the richness using EstimateS software (version 9.1.0) (Colwell, 2013). Among the set of estimators Chao1 was selected owing to its high precision in estimating richness (Hortal, Borges, \& Gaspar, 2006). We then generated a species accumulation curve using this estimator and observed richness in order to ensure the completeness of the sampling. The Shannon-Wiener diversity index $\left(\mathrm{H}^{\prime}\right)$ was calculated as the component of alpha diversity (Pielou, 1969; Shannon \& Weaver, 1949) using the 
formulae given below:

$$
\text { Shannon-Wiener diversity index }\left(\mathrm{H}^{\prime}\right)=-\Sigma p_{i} \ln p_{i}
$$

where $p_{i}=$ proportion of the total sample belonging to the $i$ th species; $1 n=$ natural logarithm.

$$
\text { Evenness }(\mathrm{J})=\mathrm{H}^{\prime} / \mathrm{H}_{\max }
$$

where $\mathrm{H}_{\max }=\ln S ; S=$ number of species; $\mathrm{H}^{\prime}=$ Shannon-Weiner diversity index.

To compare the alpha diversity and its associated parameters between TRC and NFS, we followed two distinct approaches. First, we applied the Mann-Whitney U test (the data assumed non-parametric distribution) to test the significance in variation between the community parameters of TRC and NFS. Second, in order to estimate the magnitude of difference in diversity of the two communities, the effective number of species (ENS), also known as Hill's number, was estimated. Effective number of species is estimated as the exponent of the Shannon-Weiner diversity index and represents the number of equally abundant species required to produce a particular value of diversity.

Beta diversity between TRC and NFS was calculated based on incidence and abundance matrix and partitioned into its respective components. To explain beta diversity in terms of incidence, Sorensen dissimilarity index $\left(\beta_{\mathrm{SOR}}\right)$ was calculated for total beta diversity, Simpson dissimilarity $\left(\beta_{\mathrm{SIM}}\right)$ as turnover component and nestedness resultant $\left(\beta_{\mathrm{NES}}\right)$ as its nestedness component, following Baselga (2010). For abundance-based dissimilarity measurement, total beta diversity was calculated as Bray-Curtis dissimilarity $\left(\mathrm{d}_{\mathrm{BC}}\right)$ and then partitioned into balanced variation in abundances $\left(\mathrm{d}_{\mathrm{BC}-\mathrm{bal}}\right)$, which complements species turnover and abundance gradients ( $\left.\mathrm{d}_{\mathrm{BC} \text {-gra }}\right)$ as a complement of species nestedness (Baselga, 2013). Permutational multivariate analysis of variance (PERMANOVA) and non-metric multidimensional scaling (NMDS) was performed based on Bray-Curtis dissimilarity to understand the variation between the TRC and NFS Odonata community assemblages. All statistical analysis was performed in R software version 3.4.3 using vegan (Oksanen et al., 2016) and betapart (Baselga et al., 2018) packages. We then summarized the differences in community by comparing the community assemblages at family level between the TRC and NFS, because the differences are more pronounced at family level as suggested by Sigutova, Sipos, and Dolny (2019).

\section{Results}

\section{Diversity and abundance}

A total of 881 individual odonates representing 31 species in two suborders and seven families were recorded during this study (Appendix 1; Figures 3, 4). Suborders Anisoptera and Zygoptera represented 16 and 15 species, respectively. TRC consisted of 20 species representing three families and NFS had 18 species representing seven families (Appendix 1; Table 2). Estimated species richness (Chao1) was higher in the TRC ( $20 \pm 0.31)$ compared to NFS $(19.49 \pm 2.59)$. The values of observed species richness and Chaol were almost similar for TRC, indicating completeness of sampling. Chaol estimated relatively higher values of species richness than the observed richness of the odonates in NFS, indicating that a few additional species may be recorded on further sampling. Species accumulation curves for both TRC and NFS almost reached an asymptote, indicating completeness of the sampling effort (Figure 5). Other community parameters such as Shannon-Wiener diversity index, evenness and effective number of species (ENS) differed between the two communities (Table 2). However, the difference in the community parameters between the study systems was not statistically significant. The ENS 


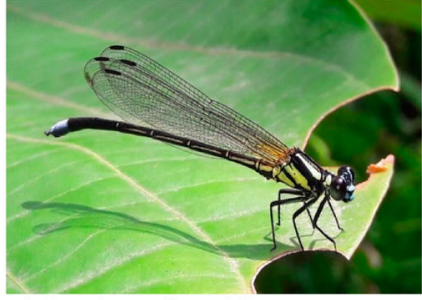

Anisopleura lestoides

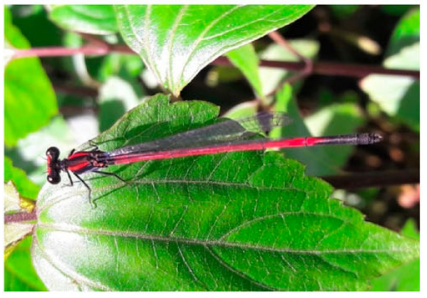

Calicnemia miniata

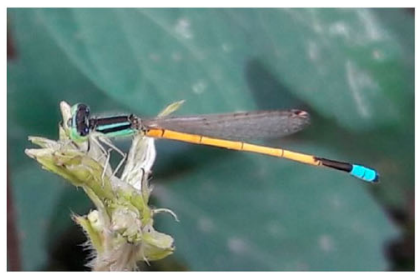

Ischnura aurora

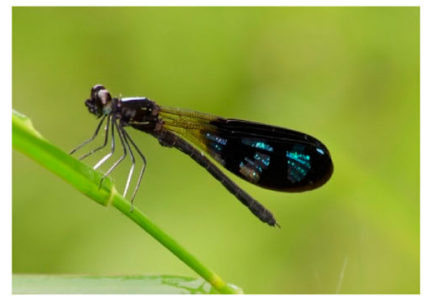

Aristocypha cuneata

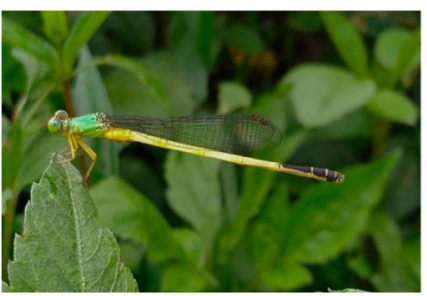

Ceriagrion fallax

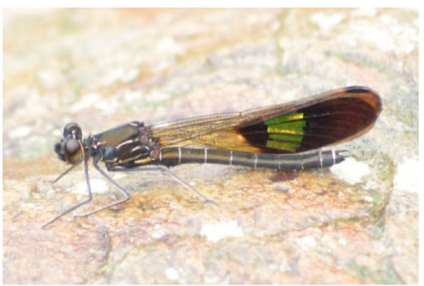

Rhinocypha unimaculata

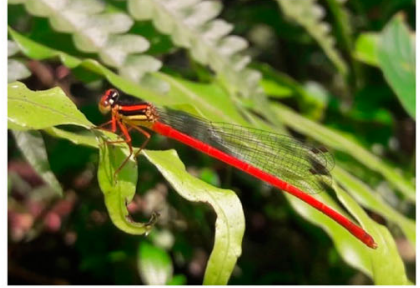

Calicnemia eximia

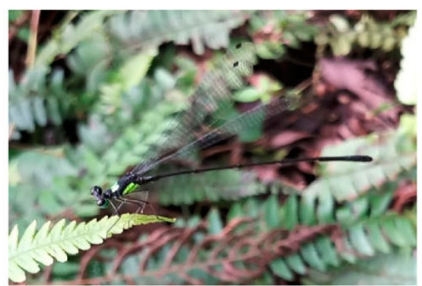

Coeliccia renifera

Figure 3. Photographs of some of the damselflies (Zygoptera) recorded during the study in Sikkim, Eastern Himalaya

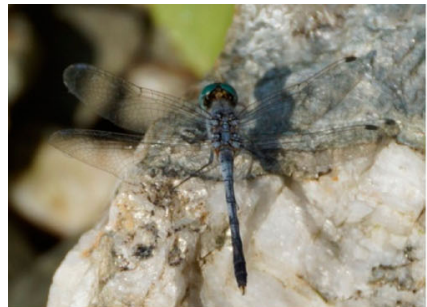

Diplacodes trivialis

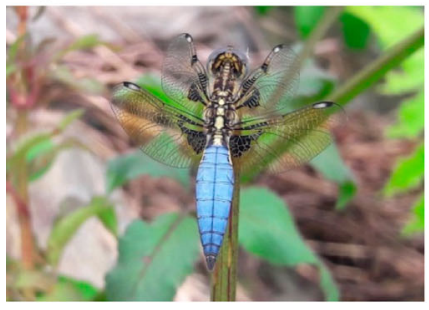

Palpopleura sexmaculata

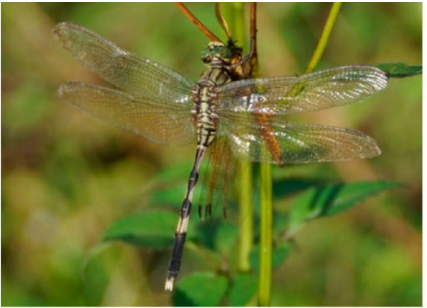

Orthetrum sabina

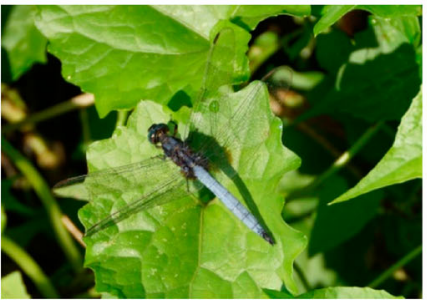

Orthetrum glaucum

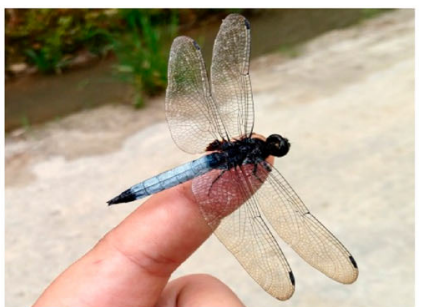

Orthetrum triangulare

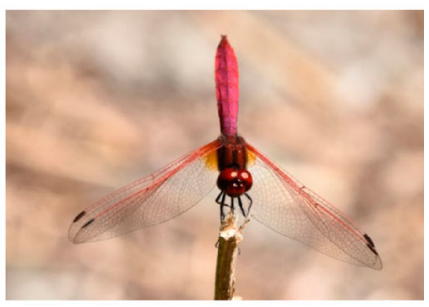

Trithemis aurora

Figure 4. Photographs of some of the dragonflies (Anisoptera) recorded during the study in Sikkim, Eastern Himalaya 
Table 2. Community parameters of odonates of terrace rice cultivation (TRC) and natural forest system with streams (NFS) in Sikkim, Eastern Himalaya.

\begin{tabular}{lcccc}
\hline S1 no & Community parameter & TRC & NFS & Total \\
\hline 1 & Species richness & 20 & 18 & 31 \\
2 & Total abundance & 639 & 242 & 881 \\
3 & Shannon-Wiener diversity & 2.63 & 2.47 & 2.55 \\
4 & Evenness & 0.88 & 0.84 & 0.86 \\
5 & Chao1 \pm SD & $20 \pm 0.31$ & $19.49 \pm 2.59$ & - \\
6 & Effective number of species & 13.96 & 11.91 & \\
\hline
\end{tabular}
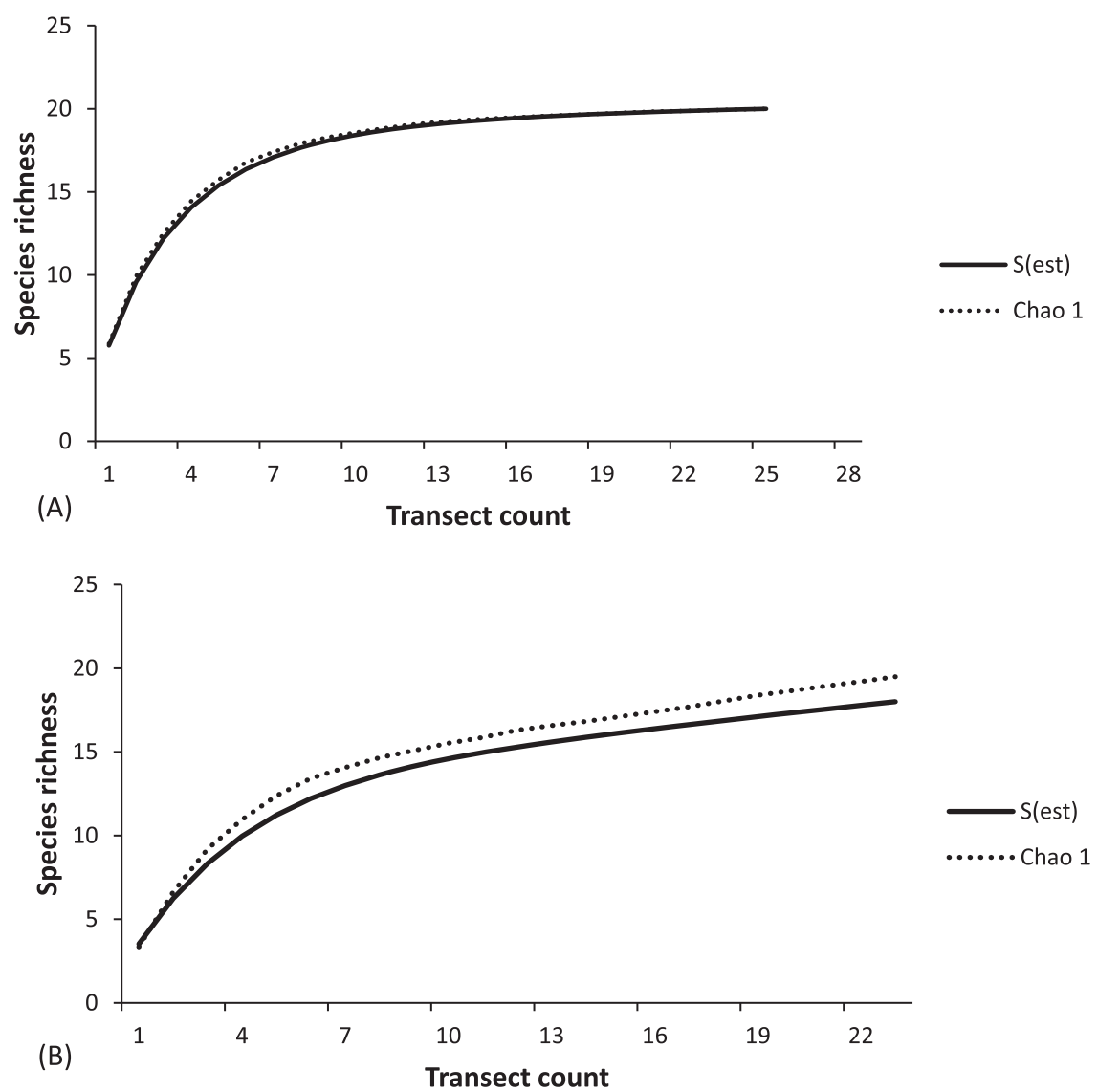

Figure 5. Species accumulation curve in (A) terrace rice cultivation (TRC) and (B) natural forest system with streams (NFS) in Sikkim, Eastern Himalaya. S(est)-observed species; Chao1-non parametric species richness estimator.

value of the TRC and NFS were 13.96 and 11.91, respectively, indicating that the TRC was slightly more diverse than the NFS. A higher number of individuals $(n=639)$ was recorded from the TRC as compared to the NFS $(\mathrm{n}=242)$. In the TRC, Palpopleura sexmaculata was the most abundant species, constituting about $15.02 \%$ of the total odonates observed, followed by Orthetrum glaucum (12.37\%) and Orthetrum triangulare (11.90\%). Similarly, Anisopleura lestoides was the most abundant species, comprising $24.80 \%$ of the total odonates recorded in the NFS, followed by Calicnemia eximia (9.91\%) and Orthetrum glaucum (9.09\%). 
Table 3. Beta diversity between terrace rice cultivation and natural forest system with streams based on incidence based and abundance based dissimilarity matrices in Sikkim, Eastern Himalaya.

\begin{tabular}{lcc}
\hline Indices & $\begin{array}{c}\text { Incidence based } \\
\text { dissimilarity }\end{array}$ & $\begin{array}{c}\text { Abundance based } \\
\text { dissimilarity }\end{array}$ \\
\hline Turnover/abundance balance & $0.588\left(\beta_{\mathrm{SIM}}\right)$ & $0.61\left(\mathrm{~d}_{\mathrm{BC}-\mathrm{bal}}\right)$ \\
Nestedness/abundance gradient & $0.05\left(\beta_{\mathrm{NES}}\right)$ & $0.17\left(\mathrm{~d}_{\mathrm{BC}-\mathrm{gar}}\right)$ \\
Total beta diversity & $0.63\left(\beta_{\mathrm{SOR}}\right)$ & $0.78\left(\mathrm{~d}_{\mathrm{BC}}\right)$ \\
\hline
\end{tabular}

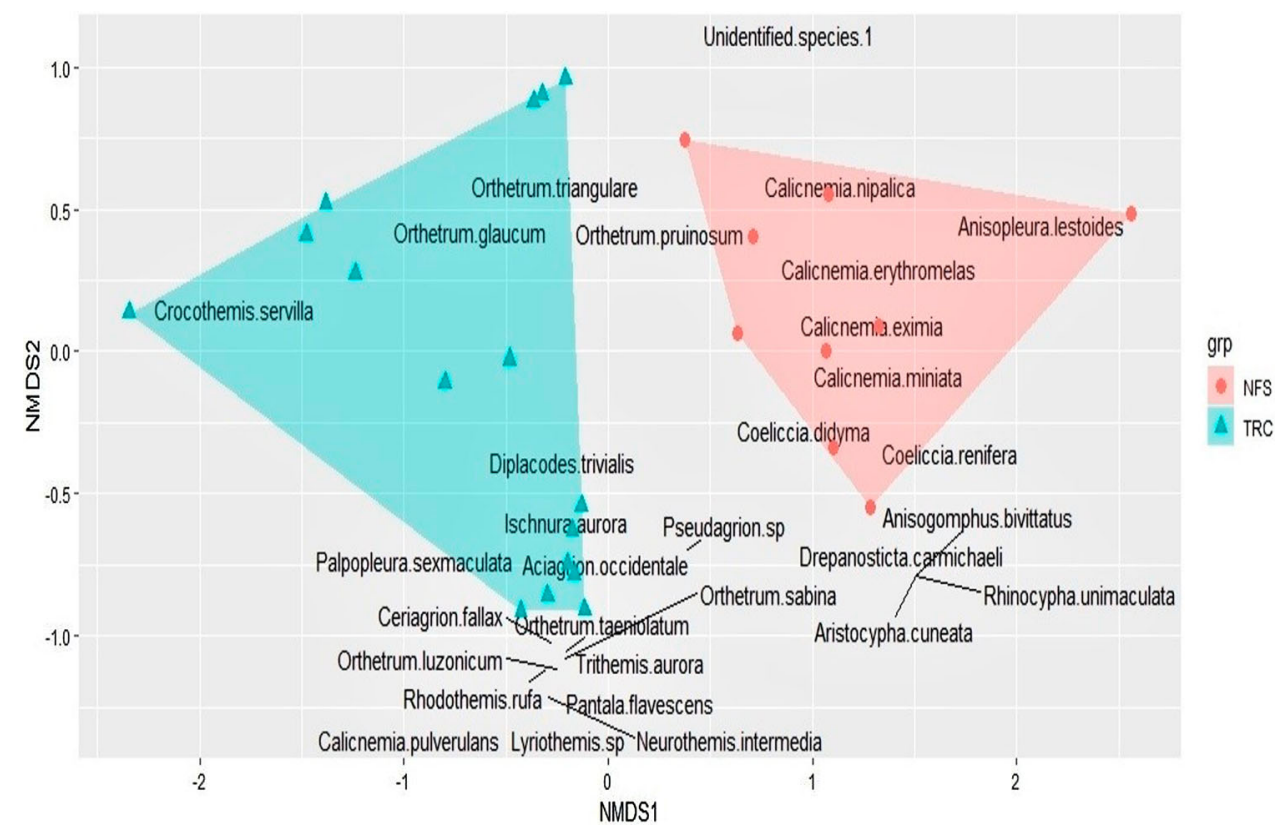

Figure 6. Non-metric multidimensional scaling plot showing clustering of terrace rice cultivation (TRC)/natural forest system with streams (NFS) habitat transects and species assemblage (based on Bray-Curtis dissimilarity)

\section{Beta diversity pattern}

Both incidence based $\left(\beta_{\mathrm{SOR}}=0.63\right)$ and abundance based matrices $\left(\mathrm{d}_{\mathrm{BC}}=0.78\right)$ of beta diversity measurement showed high diversity between the two habitats (Table 3). Partitioning of beta diversity showed that the turnover component contributed most to beta diversity. Nonmetric multidimensional scaling plot (stress $=0.092$ ) showed distinct clusters of two habitat types depicting distinct species assemblages (Figure 6). Among the 31 observed species, seven species were common to two habitat types, whereas 13 species were unique to TRC and 11 were exclusive to NFS (Appendix 1). Species of the genera Calicnemia and Coeliccia made distinct clusters of forest species. Similarly, generalist species such as Orthetrum triangulare, Orthetrum glaucum, Crocothemis servilia, Diplacodes trivialis, Ischnura aurora and Palpopleura sexmaculata formed a distinct cluster inhabiting the TRC system. PERMANOVA analysis showed statistically significant variation in odonate community between the two habitats $(p<0.001)$ (Table 4). 
Table 4. PERMANOVA results for terrace rice cultivation and natural forest system with streams in Sikkim, Eastern Himalaya based on Bray-Curtis distances.

\begin{tabular}{lccccl}
\hline & d.f. & SS & MS & Pseudo F & \multicolumn{1}{c}{$\mathrm{R}^{2 \mathrm{a}, \mathrm{b}}$} \\
\hline Habitat & 1 & 1.7358 & 1.73578 & 7. & $0.24334^{* * * *}$ \\
Residuals & 23 & 5.3974 & 0.23467 & & $\begin{array}{l}0.75666 \\
1\end{array}$ \\
Total & 24 & 7.1332 & & & 1 \\
\hline
\end{tabular}

Abbreviations: SS, sum of squares; MS, mean sum of squares.

a Significance value based on 999 permutation.

b Significance level: ${ }^{* * *} p<0.001$.

\section{Family wise pattern}

Odonates representing seven families, Libellulidae, Gomphidae, Euphaeidae, Platycnemididae, Coenagrionidae, Chlorocyphidae and Platystictidae, were recorded during the study. Odonates belonging to all seven families were observed in NFS. Platycnemididae comprised of $38.89 \%$ of total species recorded in this habitat, represented by seven species, followed by Libellulidae $(22.22 \%)$ with four species, and Chlorocyphidae and Coenagrionidae (11.11\%) with two species each. Euphaeidae, Gomphidae, and Platystictidae comprised 5.56\% of species, with one species each. In terms of relative abundance, Platycnemididae was the most abundant $(37.20 \%$ of total individuals), followed by Libellulidae (28.92\%), Euphaeidae (24.80\%), Coenargrionidae (7.03\%), Platystictidae (0.82\%), Chlorocyphidae (0.82\%) and Gomphidae (0.41\%).

Of the seven families, only three (Libellulidae, Coenagrionidae and Euphaeidae) were recorded in the TRC. Libellulidae was the most dominant family in the TRC (75\%), represented by 15 species, followed by Coenagrionidae (20\%) with four species and Euphaeidae (5\%), represented by only one species. A similar pattern was observed in relative abundance of the families, with Libellulidae being the most abundant family (79.03\%), followed by Coenagrionidae $(20.03 \%)$ and Euphaeidae (0.94\%).

\section{Discussion}

This is the first systematic study on odonate communities of the agricultural landscape of Sikkim, an organically farming state of India. The total species recorded during the present study (31 species) represent about $40.2 \%$ of the total number of species recorded from the Sikkim Himalayan region (Mitra, 2003, 2004; Payra \& Bhutia, 2017). Non-parametric estimators estimated slightly higher number of species than observed species richness, indicating the chance of encountering a few more species with additional sampling. However, the asymptotic pattern of species accumulation curve indicates completeness of the sampling.

Alpha diversity and abundance were slightly higher in the TRC compared to NFS. Other studies have also reported higher abundance and richness of odonates in agricultural land compared to forest areas (Hofhansl \& Schneeweihs, 2008; Seidu et al., 2017). However, the differences in alpha diversity parameters between the two communities were statistically non-significant in our study. This suggests that the two communities are characterized by almost equitable patterns of alpha diversity, with TRC slightly more diverse than the NFS. The diversity of odonates within the TRC was maintained mainly due to the influx of species with high adaptability to open habitat conditions and their tolerance to moderate levels of habitat disturbances, even though forest species were being lost. Hence, the inference based only on alpha diversity measures (species richness count and its derivative) may not be adequate to compare the two communities, because the real differences were in the distinct species compositions of the two communities. We observed high beta diversity between the habitats which are mostly dominated by substitution 
components reflecting distinct community assemblages. Similar results have been obtained by a study in Mexico which shows that the land use conversion affects the species composition of adult odonates but not the species richness (Rocha-Ortega, Rodrigurz, \& Cordoba-Aguilar, 2018).

The beta diversity estimates showed that the community composition of the odonates differed qualitatively (incidence measure) and quantitatively (abundance measure) between the two land use types. The turnover component (abundance balance in case of abundance based beta diversity measure) had a higher contribution in the overall beta diversity, suggesting that one species assemblage is being replaced by another due to environmental sorting (Baselga, 2010). This high percentage of dissimilarity indicates the uniqueness of the two habitat types as shown in the NMDS plot (Figure 6). NFS is a natural habitat with streams, and harbours a specialist community with less tolerance to environment changes, whereas the TRC habitat is widespread, supporting rich micro fauna and common species with frequent occurrence of individuals that can survive in various environmental conditions (Elanchezhyan, Sowmiya, Agilesh, \& Venkatesh, 2017). TRC in this region is characterized by landscape modification to support rice cultivation. Altered habitats tend to alter species assemblages of odonates and favour generalist species which can tolerate wide range of habitat type (Clausnitzer, 2003; Stewart \& Samways, 1998). Species richness was slightly higher in TRC compared to NFS but high turnover highlights the importance of both ecosystems in maintenance and conservation of odonates and associated biodiversity. Similar alpha diversity and high beta diversity between the systems highlights that human-modified ecosystems such as TRC are equally effective as forest ecosystem in conservation and maintenance of odonate diversity.

In the TRC system, the odonate community was mostly dominated by generalist species. Libellulidae of the suborder Anisoptera was found to be most dominant family and species such as Palpopleura sexmaculata, Orthetrum glaucum and Orthetrum triangulare of the same family were most abundant. These species are reported to have wide distributional range and can breed in wide array of microhabitats, but often prefer marshy lentic habitats (Dow, 2009a, 2009b, 2010a). Orthetrum triangulare in particular is known to be tolerant to disturbances and can be considered as an indicator of habitat alteration (Dow, 2010a). Additionally, most of the species under family Libellulidae are swift fliers, which requires open areas for active thermoregulation to compensate for the energy lost during their flight (Corbet \& May, 2008; Seidu et al., 2017). The dominance of Libellulidae in the rice cultivation ecosystem has been reported by many other studies as well (Dwari \& Mondal, 2017; Kulkarni \& Subramanian, 2013; Rohmare et al., 2016). Open habitats such as TRC offer more favourable thermal microhabitats than forest, where the canopy of trees offers a cooler environment. Similarly, the Coenagrionidae family of the suborder Zygoptera were represented by species such Ischnura aurora and Aciagrion occidentale, which are associated with open and disturbed habitats (Dow, Rowe, \& Marinov, 2013; Mitra, 2010; Sigutova et al., 2019).

NFS harboured the highest diversity of Zygoptera among the recorded odonate families. Most zygopterans requires vegetative substrate for oviposition and hence are favoured in habitats with good vegetation cover (Seidu et al., 2017). In NFS, Platycnemididae was the most dominant family both in terms of species richness and abundance. The species of this family, such as Calicnemia sp. and Coeliccia renifera, were restricted to forest habitat because of their dependency on the forest for breeding (Dow, 2010b, 2010c). Similarly, the two families of Zygoptera, namely Platystictidae and Chlorocyphidae, were rare and strictly confined to forest habitat. Anisopleura lestoides, belonging to family Euphaeidae, was found to be particularly dominant in the NFS but was found to occur in the TRC (mostly in the margins with some vegetation cover) in less abundance. Since Euphaeidae can tolerate habitat modification to some extent, it may completely disappear only with extensive alteration of natural habitat (Subramanian, Ali, \& Ramchandra, 2008). 
In summary, our study assessed odonate diversity in the TRC and NFS in the Sikkim Himalaya. We found significant differences in community assemblages of odonates in these two land use types. Our results indicate that nature-friendly farming practices with remnant forest patches in the rice cultivation landscape are able to sustain the diversity of forest specialist groups of odonates. In contrast to intensive agriculture practices around the world, the traditional and organic farming practice in the Sikkim Himalayan region ensures the preservation of remnant forest patches in its surroundings. Considering the intensification of agriculture in tropical countries, the role of remnant patches in conserving the biodiversity is well appreciated across the globe (Hansen, Scheele, Driscoll, \& Lindenmayer, 2019). We are, however, uncertain on how different environmental, spatial or biotic variables affect odonates in this landscape, since we did not evaluate these factors during the study. It has been reported that gradients of forest degradation, area of forest patch and level of disturbances causes shift in odonate communities (Dolny, Barta, Lhota, \& Drozd, 2012; Luke et al., 2017; Sigutova et al., 2019). Subsequently, it has been reported that insecticide usage, water quality, ditch size and structure of bank vegetation in the rice agroecosystem significantly affect the odonate community (Baba et al., 2019; Giuliano \& Bogliani, 2019). Hence, it is important in the future to understand these processes and to identify key components that shape community assemblage of the odonates in this agricultural landscape.

\section{Conclusion}

The study highlighted the effect of habitat changes on odonate assemblages in organic agricultural landscapes of Sikkim Himalaya. The TRC system had higher species richness and abundance which was mostly dominated by the generalist species. On the other hand, NFS had the richer family level diversity with most of the species specialized to forest habitat. The rice cultivated areas thus represent an example of an altered habitat. However, the adjoining forest patches also form an integral part of the agricultural landscape and compensate for the loss of habitat for odonates, and serve as a refuge for the forest specialist species.

It is to be noted that the lowland areas of Sikkim have only $6 \mathrm{~km}^{2}$ area under protected area network (PA) and further expansion of PAs is not possible in these human-dominated landscapes. The remnant forest patches retained within traditional cultivated systems in Sikkim Himalaya can be an important alternative to the PAs in conservation of biodiversity. Further studies documenting various taxa such as herpetofauna in this agricultural ecosystem, and the ecosystem services associated with them, may be crucial for planning conservation strategies. Studies on structural and species composition, effective area and disturbance gradients of the forest patches and their interactions would be crucial for future conservation planning. While our results suggest that organic agricultural farms are important for conservation of odonates and associated biodiversity, extensive studies involving more traditional farms across the state (or in the other parts of Eastern Himalaya) would provide us with a better understanding of the biodiversity conservation potential of these unique ecosystems in the Himalaya.

\section{Acknowledgements}

We thank Sikkim University for facilities to undertake this research and Ashoka Trust for Research in Ecology and Environment (ATREE) for their collaboration in the project. We are grateful to Forests, Environment and Wildlife Management Department, Government of Sikkim for providing a research permit. We thank other research fellows of the NMHS project, field assistants and farm owners of the study area for their support and cooperation.

\section{Funding}

This paper is an outcome of the project funded by the Ministry of Environment, Forest and Climate Change, Government of India through G B Pant National Institute of Himalayan Environment and Sustainable Environment, Uttarakhand under the National Mission on Himalayan Studies [grant number: NMHS-2017/MG-01/477]. 


\section{ORCID}

Sailendra Dewan (D) http://orcid.org/0000-0002-2730-6910

Bhoj Kumar Acharya (D) http://orcid.org/0000-0003-3936-1682

\section{References}

Acharya, B. K., Sanders, N. J., Vijayan, L., \& Chettri, B. (2011). Elevational gradients in bird diversity in the Eastern Himalaya: an evaluation of distribution patterns and their underlying mechanisms. PLoS One, 6(12), e29097. doi:10.1371/journal.pone.0029097

Allen, D. J., Molur, S., \& Daniel, B. A. (2010). The status and distribution of freshwater biodiversityin the Eastern Himalaya. Cambridge/Coimbatore, India: IUCN/Zoo Outreach Organisation.

Anbalagan, V., Paulraj, M. G., \& Ignacimuthu, S. (2013). Odonata diversity (Insecta: Arthropoda) in rice and vegetable fields in a north-eastern district of Tamil Nadu, India. Journal of Research in Biology, 3(4), 977-983. Retrieved from http://jresearchbiology.com/documents/RA0346.pdf

Baba, Y. G., Kusumoto, Y., \& Tanaka, K. (2019). Positive effect of environmentally friendly farming on paddy field odonate assemblages at a small landscape scale. Journal of Insect Conservation, 23(3), 467-474. doi:10.1007/s10841-019-00132-2

Baselga, A. (2010). Partitioning the turnover and nestedness components of beta diversity. Global Ecology and Biogeography, 19(1), 134-143. doi:10.1111/j.1466-8238.2009.00490.x

Baselga, A. (2013). Separating the two components of abundance-based dissimilarity: balanced changes in abundance vs. abundance gradients. Methods in Ecology and Evolution, 4(6), 552-557. doi:10.1111/2041-210X. 12029

Baselga, A., Orme, D. L., Villeger, S., Bortoli, J. D., Leprieur, F., \& Baselga, M. A. (2018). betapart: R package version 3.5.1. https://cran.r-project.org.

Bhutia, D. T. (2015). Sikkim Organic Mission "Journey of a fully organic state". Department of Food Security \& Agriculture Development and Horticulture and Cash Crops Development, Government of Sikkim, Gangtok.

Brooks, T. M., Mittermeier, R. A., Mittermeier, C. G., Da Fonseca, G. A., Rylands, A. B., Konstant, W. R., HiltonTaylor, C. (2002). Habitat loss and extinction in the hotspots of biodiversity. Conservation Biology, 16(4), 909-923. doi:10.1046/j.1523-1739.2002.00530.x

Chettri, P. K., Sharma, K., Dewan, S., \& Acharya, B. K. (2018). Butterfly diversity in human-modified ecosystems of southern Sikkim, the eastern Himalaya, India. Journal of Threatened Taxa, 10(5), 11551-11565. doi:10.11609/jott.3641.10.5.11551-11565

Chitra, G. A., Muraleedharan, V. R., Swaminathan, T., \& Veeraraghavan, D. (2006). Use of pesticides and its impact on health of farmers in South India. International Journal of Occupational and Environmental Health, 12(3), $228-233$. doi:10.1179/oeh.2006.12.3.228

Chung, A. Y. C., Eggleton, P., Speight, M. R., Hammond, P. M., \& Chey, V. K. (2000). The diversity of beetle assemblages in different habitat types in Sabah, Malaysia. Bulletin of Entomological Research, 90(6), 475-496. doi:10.1017/S0007485300000602

Clausnitzer, V. (2003). Dragonfly communities in coastal habitats of Kenya: indication of biotope quality and the need of conservation measures. Biodiversity \& Conservation, 12(2), 333-356. doi:10.1023/A:1021920402913

Clausnitzer, V., Kalkman, V. J., Ram, M., Collen, B., Baillie, J. E., Bedjanič, M., .. Karube, H. (2009). Odonata enter the biodiversity crisis debate: the first global assessment of an insect group. Biological Conservation, 142(8), 18641869. doi:10.1016/j.biocon.2009.03.028

Colwell, R. K. (2013). EstimateS, Version 9.1: Statistical estimation of species richness and shared species from samples. Software and User's Guide. Freeware published at http://viceroy.eeb.uconn.edu/estimates.

Corbet, P. S. (1999). Dragonflies: behaviour and ecology of Odonata. Colchester: Harley Books.

Corbet, P. S., \& May, M. L. (2008). Fliers and perchers among Odonata: dichotomy or multidimensional continuum? A provisional reappraisal. International Journal of Odonatology, 11(2), $155-171$. doi:10.1080/13887890.2008.9748320

Czech, H. A. (2002). Agricultural wetlands and water birds: a review. Waterbirds, 25, 56-65. Retrieved from www.jstor.org/stable/1522452

Dalzochio, M. S., Baldin, R., Stenert, C., \& Maltchik, L. (2016). Can organic and conventional agricultural systems affect wetland macroinvertebrate taxa in rice fields? Basic and Applied Ecology, 17(3), $220-229$. doi:10.1016/j.baae.2015.10.009

Dolny, A., Barta, D., Lhota, S., \& Drozd, P. (2012). Aquatic insects indicate terrestrial habitat degradation: changes in taxonomical structure and functional diversity of dragonflies in tropical rainforest of East Kalimantan. Tropical Zoology, 25, 141-157. doi:10.1080/03946975.2012.717480

Dow, R. A. (2009a). Palpopleura sexmaculata. The IUCN Red List of Threatened Species 2009:e.T163719A5641056. Retrieved October 9, 2019, from http://doi.org/10.2305/IUCN.UK.2009-2.RLTS.T163719A5641056.en.

Dow, R. A. (2009b). Orthetrum glaucum. The IUCN Red List of Threatened Species 2009: e.T163780A5650496. Retrieved October 9, 2019, from http://doi.org/10.2305/IUCN.UK.2009-2.RLTS.T163780A5650496.en.

Dow, R. A. (2010a). Orthetrum triangulare. The IUCN Red List of Threatened Species 2010: e.T167098A6301833. Retrieved October 9, 2019, from http://doi.org/10.2305/IUCN.UK.2010-4.RLTS.T167098A6301833.en. 
Dow, R. A. (2010b). Calicnemia miniata. The IUCN Red List of Threatened Species 2010: e.T167356A6333588. Retrieved October 9, 2019, from http://doi.org/10.2305/IUCN.UK.2010-4.RLTS.T167356A6333588.en.

Dow, R. A. (2010c). Coeliccia renifera. The IUCN Red List of Threatened Species 2010: e.T167311A6327354. Retrieved October 9, 2019, from http://doi.org/10.2305/IUCN.UK.2010-4.RLTS.T167311A6327354.en.

Dow, R. A., Rowe, R., \& Marinov, M. (2013). Ishurna aurora. The IUCN Red List of Threatened Species 2013: e.T167375A1177456. Retrieved October 9, 2019, from http://doi.org/10.2305/IUCN.UK.2010-1.RLTS. T167375A1177456.en.

Dwari, S., \& Mondal, A. K. (2017). Diversity of Odonates in agricultural fields of Howrah district, West Bengal, India. Journal of Entomology and Zoology Studies, 5(3), 1588-1595. Retrieved from http://www.entomoljournal.com/archives/2017/vol5issue3/PartV/5-1-182-920.pdf

Elanchezhyan, K., Sowmiya, C., Agilesh, S., \& Venkatesh, M. (2017). Diversity of odonates at agricultural college campus, Killikulam, Tamil Nadu, India. Journal of Entomology and Zoology Studies, 5(5), 935-940. Retrieved from http://www.entomoljournal.com/archives/2017/vol5issue5/PartM/5-4-372-563.pdf

Fraser, F. C. (1933). The Fauna of British India including Ceylon and Burma. Odonata vol. I. London: Taylor and Francis.

Fraser, F. C. (1934). The Fauna of British India including Ceylon and Burma. Odonata vol. II. London: Taylor and Francis.

Fraser, F. C. (1936). The Fauna of British India including Ceylon and Burma. Odonata vol. III. London: Taylor and Francis.

Gibbons, L. K., Reed, J. M., \& Chew, F. S. (2002). Habitat requirements and local persistence of three damselfly species (Odonata: Coenagrionidae). Journal of Insect Conservation, 6(1), 47-55. doi:10.1023/A:1015754015603

Giuliano, D., \& Bogliani, G. (2019). Odonata in rice agroecosystems: Testing good practices for their conservation. Agriculture, Ecosystems \& Environment, 275, 65-72. doi:10.1016/j.agee.2019.01.009

Godfray, H. C. J., Beddington, J. R., Crute, I. R., Haddad, L., Lawrence, D., Muir, J. F., \& Toulmin, C. (2010). Food security: the challenge of feeding 9 billion people. Science, 327(5967), 812-818. doi:10.1126/science.1185383

Hansen, N. A., Scheele, B. C., Driscoll, D. A., \& Lindenmayer, D. B. (2019). Amphibians in agricultural landscapes: the habitat value of crop areas, linear plantings and remnant woodland patches. Animal Conservation, 22, $72-82$. doi:10.1111/acv.12437

Hofhansl, F. P., \& Schneeweihs, S. (2008). Banderillas: Effects of deforestation on dragonflies (Insecta, Odonata) in the Pacific lowland of Costa Rica. Zugleich Kataloge der oberosterreichischen Landesmuseen Neue Serie, 80, 237-247. Retrieved from https://www.researchgate.net/publication/228084169

Hortal, J., Borges, P. A., \& Gaspar, C. (2006). Evaluating the performance of species richness estimators: sensitivity to sample grain size. Journal of Animal Ecology, 75(1), 274-287. doi:10.1111/j.1365-2656.2006.01048.x

IUCN. (2015). Conservation successes overshadowed by more species declines - IUCN Red List update. Retrieved July 31, 2019, from http://www.iucnredlist.org/news/conservation-successes-overshadowed-by-more-species-declinesiucn-red-list-update.

Jadhao, M. F., \& Khurad, A. M. (2011). Insect pests complex of rice ecosystem in eastern vidarbha of Maharashtra, India. Research Analysis and Evaluation, 2(24), 19-21.

Joshi, S., Dawn, P., Roy, P., \& Kunte, K. (Eds.) (2019). Odonata of India, v. 1.48. Banglore: Indian Foundation for Butterflies. Retrieved from https://www.indianodonata.org/publications

Kadoya, T., Suda, S. I., \& Washitani, I. (2009). Dragonfly crisis in Japan: a likely consequence of recent agricultural habitat degradation. Biological Conservation, 142(9), 1899-1905. doi:10.1016/j.biocon.2009.02.033

Kandibane, M., Raguraman, S., \& Ganapathy, N. (2005). Relative abundance and diversity of Odonata in an irrigated rice field of Madurai, Tamil Nadu. Zoos' Print Journal, 20(11), 2051-2052. Retrieved from https://pdfs.semanticscholar.org/9df5/0b106bb0cf58f583d1836986546a14a83d23.pdf

Katayama, N., Osada, Y., Mashiko, M., Baba, Y. G., Tanaka, K., Kusumoto, Y., \& Natuhara, Y. (2019). Organic farming and associated management practices benefit multiple wildlife taxa: A large-scale field study in rice paddy landscapes. Journal of Applied Ecology, 56(8), 1970-1981. doi:10.1111/1365-2664.13446

Khatiwada, J. R., Ghimire, S., Khatiwada, S. P., Paudel, B., Bischof, R., Jiang, J., \& Haugaasen, T. (2016). Frogs as potential biological control agents in the rice fields of Chitwan, Nepal. Agriculture, Ecosystems \& Environment, 230, 307-314. doi:10.1016/j.agee.2016.06.025

Kulkarni, A. S., \& Subramanian, K. A. (2013). Habitat and seasonal distribution of Odonata (Insecta) of Mula and Mutha river basins, Maharashtra, India. Journal of Threatened Taxa, 5(7), 4084-4095. doi:10.11609/JoTT.o3253.4084-95

Kurniawan, N., Yanuwiadi, B., Priambodo, B., Maulidi, A., \& Kurnianto, A. S. (2016). Various vegetation modifies the diversity of herpetofauna in wonosobo agricultural landscape. Journal of Environmental Engineering \& Sustainable Technology, 4(2), 138-142. doi:10.21776/ub.jeest.2017.004.02.10

Lawton, J. H., Bignell, D. E., Bolton, B., Bloemers, G. F., Eggleton, P., Hammond, P. M., \& Stork, N. E. (1998). Biodiversity inventories, indicator taxa and effects of habitat modification in tropical forest. Nature, 391(6662), 72. doi: $10.1038 / 34166$

Lichtenberg, E. M., Kennedy, C. M., Kremen, C., Batary, P., Berendse, F., Bommarco, R., \& Winfree, R. (2017). A global synthesis of the effects of diversified farming systems on arthropod diversity within fields and across agricultural landscapes. Global Change Biology, 23(11), 4946-4957. doi:10.1111/gcb.13714

Luke, S. H., Dow, R. A., Butler, S., VunKhen, C., Aldridge, D. C., Foster, W. A., \& Turner, E. C. (2017). The impacts of habitat disturbances on adult and larval dragonflies (Odonata) in rainforest streams in Sabah, Malaysian Borneo. Freshwater Biology, 62, 491-506. doi:10.1111/fwb.12880 
Ministry of Agriculture and Farmers Welfare. (2019). A status note on Rice in India. Retrieved from https://nfsm.gov.in/StatusPaper/Rice2016.pdf.

Mitra, T. R. (2003). Insecta: Odonata. Fauna of Sikkim, State Fauna Series 9. Zoological Survey of India, (2), $125-164$. Retrieved from http://faunaofindia.nic.in/PDFVolumes/sfs/045/index.pdf

Mitra, T. R. (2004). A checklist of the Odonata of Sikkim, with some new records. Opuscula Zoologica Flumin Records, $206,1-8$

Mitra, A. (2010). Aciagrion occidentale. The IUCN Red List of Threatened Species 2010: e.T167267A6320067. Retrieved October 9, 2019, from http://doi.org/10.2305/IUCN.UK.2010-4.RLTS.T167267A6320067.en.

Newbold, T., Hudson, L. N., Hill, S. L. L., Contu, S., Lysenko, I., Senior, R. A., \& Purvis, A. (2015). Global effects of land use on local terrestrial biodiversity. Nature, 520, 45-50. doi:10.1038/nature 14324

Norris, K. (2008). Agriculture and biodiversity conservation: opportunity knocks. Conservation Letters, 1(1), 2-11. doi:10.1111/j.1755-263X.2008.00007.x

Oksanen, J., Guillaume, B. F., Friendly, M., Kindt, R., Legendre, P., McGlinn, D., \& Wager, H. (2016). Vegan: Community Ecology Package. R package version 3.5.1. https://cran.r-project.org

Payra, A., \& Bhutia, N. G. (2017). Some new records of Odonata (Insecta) fauna from Sikkim Himalaya, India. Ambient Science, 4(2), 36-37. doi:10.21276/ambi.2017.04.2.nn01

Pielou, E. C. (1969). An Introduction to Mathematical Ecology. New York: Wiley.

Primack, R. B. (2014). Essentials of Conservation Biology. Sunderland, MA: Sinauer Associates.

Rocha-Ortega, M., Rodrigurz, P., \& Cordoba-Aguilar, A. (2019). Spatial and temporal effects of land use changes as potential drivers of odonate community composition but not species richness. Biodiversity and Conservation, 28, 451-466. doi:10.1007/s10531-018-1671-2

Rohmare, V. B., Rathod, D. M., \& Parasharya, B. M. (2016). Diversity and population dynamics of Odonata (Insecta: Odonata) in rice growing area of Central Gujarat. Journal of Biological Control, 30(3), 129-137. Retrieved from https://www.researchgate.net/publication/315045588

Russi, D., ten Brink, P., Farmer, A., Badura, T., Coates, D., Förster, J., \& Davidson, N. (2013). The economics of ecosystems and biodiversity for water and wetlands. London and Brussels: IEEP.

Samways, M. J. (2003). Conservation of an endemic odonate fauna in the Seychelles Archipelago. Odonatologica, 32(2), 177-182. Retrieved from http://natuurtijdschriften.nl/record/592438

Scher, O., \& Thiery, A. (2005). Odonata, Amphibia and environmental characteristics in motorway stormwater retention ponds (Southern France). Hydrobiologia, 551(1), 237-251. doi:10.1007/s10750-005-4464-z

Seidu, I., Danquah, E., AyineNsor, C., Amaning Kwarteng, D., \& Lancaster, L. T. (2017). Odonata community structure and patterns of land use in the Atewa Range Forest Reserve, Eastern Region (Ghana). International Journal of Odonatology, 20(3-4), 173-189. doi:10.1080/13887890.2017.1369179

Shannon, C. E., \& Weaver, W. (1949). The Mathematical Theory of Communication. Illinois: The University of Illinois Press.

Sharma, G., \& Acharya, B. K. (2013). Agriculture systems and management diversity. In S. Kharel, \& J. Bhutia (Eds.), Gazetteer of Sikkim (pp. 225-259). Gangtok, Sikkim: Home Department, Government of Sikkim, India.

Sharma, K., Acharya, B. K., Sharma, G., Valente, D., Pasimeni, M. R., Petrosillo, I., \& Selvan, T. (2020). Land use effect on butterfly alpha and beta diversity in the Eastern Himalaya, India. Ecological Indicators, 110, 105605. doi:10.1016/j.ecolind.2019.105605

Sharma, E., Chettri, N., Gurung, J., \& Shakya, B. (2007). The Landscape Approach in Biodiversity Conservation. In A Regional Cooperation Framework for Implementation of the Convention on Biological Diversity in the Kangchenjunga Landscape. Kathmandu, Nepal: ICIMOD.

Sigutova, H., Sipos, J., \& Dolny, A. (2019). A novel approach involving the use of Odonata as indicators of tropical forest degradation: When family matters. Ecological Indicators, 104, 229-236. doi:10.1016/j.ecolind.2019.05.001

Soniyagandhi, M., \& Kumar, K. (2014). Impact of agrochemicals on Odonata in rice (Oryza sativa L.) ecosystem. Journal of Biopesticides, 7(1), 52. Retrieved from http://www.jbiopest.com/users/LW8/efiles/vol_7_1_52-56.pdf

Stewart, D. A., \& Samways, M. J. (1998). Conserving dragonfly (Odonata) assemblages relative to river dynamics in an African savanna game reserve. Conservation Biology, 12(3), 683-692. doi:10.1111/j.1523-1739.1998.96465.x

Subramanian, K. A. (2005). Dragonflies and damselflies of peninsular India, A Field Guide. Bangalore: Project life span, Indian Institute of Science.

Subramanian, K. A., Ali, S., \& Ramchandra, T. V. (2008). Odonata as indicators of riparian ecosystem health a case study from south western Karnataka, India. Fraseria (NS), 7, 83-95. Retrieved from http://www.ces.iisc.ernet.in/biodiversity/pubs/ces_pubs/pubs_2009/theme1_17.pdf

Subramanian, K. A., \& Babu, R. (2017). Checklist of Odonata (Insecta) of India. Version 3.0. www.zsi.gov.in.

Tscharntke, T., Klein, A. M., \& Kruess, A. (2005). Landscape perspectives on agricultural intensification and biodiversity-ecosystem service management. Ecological Letters, 8, 857-874. doi:10.1111/j.1461-0248.2005.00782.x

Tuck, S. L., Winqvist, C., Mota, F., Ahnström, J., Turnbull, L. A., \& Bengtsson, J. (2014). Land-use intensity and the effects of organic farming on biodiversity: a hierarchical meta-analysis. Journal of Applied Ecology, 51(3), 746-755. doi:10.1111/1365-2664.12219 


\section{Appendix 1: List of odonates observed during the study in Sikkim, Eastern Himalaya}

Abbreviations: TRC, terrace rice cultivation; NFS, natural forest system with streams (NFS); LC, least concern; DD, data deficient; VU, vulnerable (LC, DD and VU as categories as per IUCN 2019). + sign represents present and - represent absent.

\begin{tabular}{|c|c|c|c|c|c|}
\hline \multirow[b]{2}{*}{ Sl no } & \multirow[b]{2}{*}{ Scientific name } & \multicolumn{2}{|c|}{ Habitat } & \multirow[b]{2}{*}{ Total abundance } & \multirow[b]{2}{*}{ IUCN status } \\
\hline & & TRC & NFS & & \\
\hline \multicolumn{6}{|c|}{ Suborder Anisoptera } \\
\hline \multicolumn{6}{|c|}{ Family Libellulidae } \\
\hline 1 & Orthetrum luzonicum (Brauer, 1868) & + & - & 30 & LC \\
\hline 2 & Orthetrum triangulare (Selys, 1878) & + & + & 97 & $\mathrm{LC}$ \\
\hline 3 & Diplacodes trivialis (Rambur, 1842) & + & + & 70 & LC \\
\hline 4 & Orthetrum glaucum (Brauer, 1865) & + & + & 101 & LC \\
\hline 5 & Neurothemis intermedia (Rambur, 1842) & + & - & 12 & LC \\
\hline 6 & Pantala flavescens (Fabricius, 1798) & + & - & 35 & LC \\
\hline 7 & Orthetrum sabina (Drury, 1770) & + & - & 8 & LC \\
\hline 8 & Crocothemis servilia (Drury, 1770) & + & - & 39 & LC \\
\hline 9 & Rhodothemis rufa (Rambur, 1842) & + & - & 9 & LC \\
\hline 10 & Lyriothemis sp. & + & - & 3 & LC \\
\hline 11 & Palpopleura sexmaculata (Fabricius,1787) & + & - & 96 & $\mathrm{LC}$ \\
\hline 12 & Orthetrum pruinosum (Burmeister, 1839) & + & + & 51 & LC \\
\hline 13 & Trithemis aurora (Burmeister, 1839) & + & - & 7 & LC \\
\hline 14 & Orthetrum taeniolatum (Schneider, 1845) & + & - & 14 & LC \\
\hline 15 & Unidentified species 1 & + & - & 3 & \\
\hline \multicolumn{6}{|c|}{ Family Gomphidae } \\
\hline 16 & Anisogomphus bivittatus (Selys, 1854) & - & + & 1 & DD \\
\hline \multicolumn{6}{|c|}{ Sub order Zygoptera } \\
\hline \multicolumn{6}{|c|}{ Family Platycnemididae } \\
\hline 17 & Coeliccia didyma (Selys, 1863) & - & + & 10 & LC \\
\hline 18 & Coeliccia renifera (Selys, 1886) & - & + & 15 & $\mathrm{LC}$ \\
\hline 19 & Calicnemia nipalica (Kimmins, 1958) & - & + & 10 & VU \\
\hline 20 & Calicnemia miniata (Selys, 1886) & - & + & 17 & $\mathrm{LC}$ \\
\hline 21 & Calicnemia eximia (Selys, 1863) & - & + & 24 & $\mathrm{LC}$ \\
\hline 22 & Calicnemia pulverulans (Selys, 1886) & - & + & 3 & LC \\
\hline 23 & Calicnemia erythromelas (Selys, 1891) & - & + & 11 & $\mathrm{LC}$ \\
\hline \multicolumn{6}{|c|}{ Family Coenagrionidae } \\
\hline 24 & Pseudagrion sp. & + & + & 48 & LC \\
\hline 25 & Ischnura aurora (Brauer, 1865) & + & - & 44 & $\mathrm{LC}$ \\
\hline 26 & Ceriagrion fallax (Ris, 1914) & + & - & 7 & $\mathrm{LC}$ \\
\hline 27 & Aciagrion occidentale (Laidlaw, 1919) & + & + & 46 & $\mathrm{LC}$ \\
\hline \multicolumn{6}{|c|}{ Family Chlorocyphidae } \\
\hline 28 & Aristocypha cuneata (Selys, 1853) & - & + & 1 & DD \\
\hline 29 & Rhinocypha unimaculata (Selys, 1853) & - & + & 1 & $\mathrm{LC}$ \\
\hline \multicolumn{6}{|c|}{ Family Platystictidae } \\
\hline 30 & Drepanosticta carmichaeli (Laidlaw, 1915) & - & + & 2 & $\mathrm{LC}$ \\
\hline \multicolumn{6}{|c|}{ Family Euphaeidae } \\
\hline 31 & Anisopleura lestoides (Selys, 1853) & + & + & 66 & $\mathrm{LC}$ \\
\hline
\end{tabular}

